\title{
Antioxidant, Antimicrobial and Cytotoxic Activities of Different Fractions of Citrus aurantifolia Peel
}

\section{Rupali Ghosh ${ }^{1}$, Nazia Hoque ${ }^{1}$, Meena Afroze Shanta ${ }^{1}$, Nishat Nasrin ${ }^{1}$ and Muhammad Asaduzzaman ${ }^{2}$}

\author{
${ }^{1}$ Department of Pharmacy, East West University, Aftabnagar, Dhaka- 1212, Bangladesh \\ ${ }^{2}$ Department of Clinical Pharmacy and Pharmacology, University of Dhaka, Dhaka-1000, Bangladesh
}

(Received: October 14, 2020; Accepted: November 23, 2020; Published (web): December 10, 2020)

\begin{abstract}
The present study was designed to investigate antioxidant, antimicrobial and cytotoxic effects of petroleum ether, chloroform and hydromethanol fraction of methanol extract of Citrus aurantifolia peel. Preliminary phytochemical screening of the fractions was done following the standard procedure. Antioxidant activity was measured using DPPH free radical scavenging assay besides measuring total phenolic and flavonoid content using Folin-Ciocalteu reagent and aluminum trichloride method, respectively. The antimicrobial activity was conducted by disc diffusion method and cytotoxic activity was determined by brine shrimp lethality bioassay. The results of phytochemical screening were indicative of the presence of steroids, alkaloids, saponins, glycosides, flavonoids in the fractions. A dose dependent scavenging activity was observed in DPPH radical scavenging assay where chloroform fraction demonstrated the highest activity with $\mathrm{IC}_{50}$ value of $153.68 \pm 3.60 \mu \mathrm{g} / \mathrm{ml}$. The highest phenolic content was observed in chloroform fraction (308.0 $\pm 6.55 \mathrm{mg} / \mathrm{g}$ gallic acid equivalent) and highest flavonoid content was found in hydromethanol fraction $(132.66 \pm 2.36 \mathrm{mg} / \mathrm{g}$ quercetin equivalent). The chloroform fraction showed excellent antibacterial activity against all the tested bacteria where highest zone of inhibition $(19 \mathrm{~mm})$ was produced against Bacillus cereus. In brine shrimp lethality bioassay, $\mathrm{LC}_{50}$ values for petroleum ether, chloroform and hydromethanol fractions were $367.39 \mu \mathrm{g} / \mathrm{ml}, 228.14 \mu \mathrm{g} / \mathrm{ml}$ and $296.52 \mu \mathrm{g} / \mathrm{ml}$, respectively. The present findings suggested that $C$. aurantifolia peel could be a potent source of medicinally important secondary metabolites and further investigations can be done to identify those active compounds responsible for such bioactivity.
\end{abstract}

Key words: Antioxidant, Antimicrobial, Citrus aurantifolia, DPPH, Gallic acid

\section{INTRODUCTION}

Free radicals and other reactive oxygen species (ROS) are the metabolic byproducts of oxidation and capable of performing a wide variety of functions inside the body that ranges from cellular growth to induction of apoptosis to confer immunity. ${ }^{1,2}$ But what make them infamous are their roles on lipid peroxidation and genetic mutation. These detrimental effects are linked to develop several chronic and degenerative diseases, like cardiovascular diseases, ageing, cancer, Alzheimer's disease etc. It is also now scientifically evident that, several cancer cells

Correspondence to: Nazia Hoque

Email: nzh@ewubd.edu

Dhaka Univ. J. Pharm. Sci. 19(2): 161-168, 2020 (December)

DOI: https://doi.org/10.3329/dujps.v19i2.50632 become resistant to drugs by generating higher levels of ROS making the treatments ineffective. ${ }^{3-5}$ Antioxidants actually work as electron donors to these free radicals and limit their excessive accumulation inside the body. Dietary intake of foods enriched in vitamin E, flavonoids, and polyphenols boost our body's natural antioxidant defense mechanism and slow down the maliciousness of free radicals. ${ }^{1,3,6}$ Plants abilities to fight pathogens are actually attributed to these structurally divergent secondary metabolites. Higher safety, structural biodiversities, ability to fight pathogens and scavenge free radicals fuels the interests of the researchers across the world to study medicinal plants to isolate new therapeutic entities. Furthermore, global occurrence of antimicrobial resistance with evolution of multi-drug resistant (MDR) isolates makes the 
treatment difficult and thus urges the development of new classes of therapeutic agents to combat infectious diseases. $^{7}$

Citrus aurantifolia (family: Rutaceae) is a plant from genus Citrus which is known as lemon or key lime. This plant is naturalized in various parts of the world, particularly in hot subtropical or tropical countries including Bangladesh. In Southwest Nigeria, the roots, barks, stem twigs, leaves and fruits are used in the ailment of malaria. In Malayan medicine, the fruit juice of $C$. aurantifolia is reported to act as antidote against poison and increase libido. ${ }^{8}$ C. aurantifolia is also used to treat dysfunctional uterine bleeding, diabetes, atherosclerosis, ulcer wounds and skin diseases. ${ }^{8}$ In Bangladesh, the juice is used as stomachic, antiseptic and anthelmintic; peel is used for indigestion, leaves are used as a remedy for filariasis and fruit juice is taken as a remedy of catarrhal fever. ${ }^{9}$ Studies revealed numerous pharmacological activities of different parts of $C$. aurantifolia. Leaf and root extracts were found to show antibacterial effect, fruit juice showed anticancer and antifertility effect, peel extracts possessed antidiabetic, antihyperlipidemic, and antioxidant effects. ${ }^{8,10-13}$

Literature review demonstrated very little work on methanol extracts of $C$. aurantifolia peel. As part of our ongoing research on Bangladeshi medicinal plants $^{4,14-16}$ and to establish the scientific basis of above stated traditional uses of this plant, the current study was designed to evaluate the antioxidant, antibacterial and cytotoxic potential of the various fractions of methanol extract of $C$. aurantifolia peel by various in vitro approaches.

\section{MATERIALS AND METHODS}

Chemicals and solvents. DPPH (2, 2-Diphenyl1-picrylhydrazyl) was obtained from Sigma Aldrich Co., USA. Folin-Ciocalteu reagent and ascorbic acid were purchased from Merck, Germany. All the other chemicals used, including the solvents, were of analytical grades.

Collection of plant materials and extraction procedure. Citrus aurantifolia is available throughout the country. The fruits of $C$. aurantifolia were collected from a local market of Rampura, Dhaka in February 2018 and were identified by Mr. Abdur Rahim, Technical Officer, Department of Botany, Jahangirnagar University, Savar, Bangladesh. After cleaning the whole fruits of $C$. aurantifolia, peels were separated, cut into small pieces, sun dried and pulverized to coarse powder. A total of $800 \mathrm{~g}$ of the powdered plant materials were submerged in $2.5 \mathrm{~L}$ methanol and kept for 7 days with shaking for several times. The plant extract was filtered with Markin cloth followed by sterilized cotton and Whatman number 1 filter paper. The solvent was totally evaporated using rotary evaporator under reduced pressure at $40^{\circ} \mathrm{C}-50^{\circ} \mathrm{C}$ temperature. The obtained crude extract was collected, weighed and subjected to solvent-solvent partitioning.

Solvent-solvent partitioning. Solvent-solvent partitioning of the crude methanol extract of $C$. aurantifolia peel was done using the protocol described by Rahman et al. ${ }^{17}$ The crude extract was dissolved in $10 \%$ aqueous methanol to make the mother solution which was successively partitioned with petroleum ether $(100 \mathrm{ml} \times 3)$ and chloroform (100 $\mathrm{ml} \times 3)$. The residual fraction was considered to be hydromethanol fraction. All the fractions were subjected to dryness under reduced pressure. The amount of petroleum ether, chloroform and hydromethanol soluble fractions was $1.15 \mathrm{~g}$ (23.10\%), $1.017 \mathrm{~g}$ (20.34\%) and $2.83 \mathrm{~g}(56.56 \%)$, respectively. The fractions were stored in a closed container at $4^{\circ} \mathrm{C}$ until further use.

Preliminary phytochemical screenings. All three fractions were qualitatively tested for the presence of phytochemical constituents. These were identified by characteristic color changes using standard procedures with following reagents for each phytochemicals: Molisch's reagents for carbohydrates; aqueous $\mathrm{NaOH}$ solution for glycosides; Mayer's reagent, Hager's reagent, Wagner's reagent, and Dragendorff's reagent for alkaloids; concentrated $\mathrm{HCl}$ for flavonoids; $5 \% \mathrm{FeCl}_{3}$ for tannins; chloroform followed by concentrated 
$\mathrm{H}_{2} \mathrm{SO}_{4}$ for steroids and saponins by production of frothing upon addition of distilled water. ${ }^{18}$

DPPH radical scavenging assay. The freeradical scavenging activity of $C$. aurantifolia peel fractions was measured by the ability to decrease the absorbance of methanol solution of DPPH (2,2diphenyl-1-picrylhydrazyl). ${ }^{15,19}$ Solution of DPPH having concentration of $400 \mu \mathrm{g} / \mathrm{ml}$ was prepared of which $100 \mu \mathrm{L}$ was transferred to solutions of petroleum ether (PECA), chloroform (CFCA) and hydromethanol (HMCA) fractions having different concentrations from 400 to $12.5 \mu \mathrm{g} / \mathrm{ml}$. Ascorbic acid was used as the standard which have undergone the same treatment. After $30 \mathrm{~min}$ of reaction period at room temperature in dark place, the absorbance was measured at $517 \mathrm{~nm}$ against methanol by UV-Vis spectrophotometer (Shimadzu UV PC-1600). Percent inhibition of free radical DPPH was calculated as follows:

$\%$ of free radical scavenging

$$
=\left(1-\mathrm{A}_{\text {sample/standard }} / \mathrm{A}_{\text {control }}\right) \times 100
$$

Where $A_{\text {control }}$ is the absorbance of the control (containing all reagents except the test material). Extract concentration providing $50 \%$ inhibition $\left(\mathrm{IC}_{50}\right)$ was calculated from the graph plotted percentage inhibition against extract concentration.

Total phenolic content. Total amount of phenolic compound in the fractions was determined using Folin-Ciocalteu reagent which actually measures a sample's reducing capacity. ${ }^{14,20}$ For the experiment, $1 \mathrm{ml}$ solution was prepared using PECA, CFCA and HMCA having concentration of 200 $\mu \mathrm{g} / \mathrm{ml}$ and standard gallic acid having concentration from 50 to $250 \mu \mathrm{g} / \mathrm{ml}$. A total of $5 \mathrm{ml}$ of Folinciocalteu (diluted 10 fold) reagent and $7.5 \%(\mathrm{w} / \mathrm{v})$ sodium carbonate solution was added in each preparation for proper oxidization. All experimental solutions were left for $30 \mathrm{~min}$ at $25^{\circ} \mathrm{C}$ for completion of reaction and the absorbance was taken at $765 \mathrm{~nm}$ using a UV-Vis spectrophotometer against methanol as blank. The total phenolic contents of the test samples were calculated using the calibration curve of gallic acid and expressed as $\mathrm{mg} / \mathrm{g}$ of gallic acid equivalent (GAE).
Total flavonoid content. Total flavonoids were measured using aluminum trichloride reagent. ${ }^{15,21}$ For standard, quercetin of different concentrations ranging from 50 to $250 \mu \mathrm{g} / \mathrm{ml}$ was used with and solution of PECA, CFCA and HMCA were prepared with a concentration of $200 \mu \mathrm{g} / \mathrm{ml}$. Solution of $5 \%$ $\mathrm{NaNO}_{2}$, followed by $10 \% \mathrm{AlCl}_{3}, 2 \% \mathrm{NaOH}$ and finally distilled water were added to the solution of fractions and standard. The obtained mixtures were incubated for $30 \mathrm{~min}$ at room temperature to complete reaction and then centrifuged for $15 \mathrm{~min}$ at $3000 \mathrm{rpm}$. Absorbance was measured at $510 \mathrm{~nm}$ using a UV-Vis spectrophotometer against methanol. Total flavonoid contents of the test fractions were calculated using the calibration curve of quercetin and expressed as $\mathrm{mg} / \mathrm{g}$ of quercetin equivalent (QE).

Antimicrobial activity. To assess the antimicrobial activity, disc diffusion technique was used which is widely accepted for in vitro study. ${ }^{22}$ Antimicrobial activity of PECA, CFCA and HMCA at $300 \mu \mathrm{g} /$ disc was tested against five Gram-positive and eight Gram-negative bacteria using kanamycin (30 $\mu \mathrm{g} / \mathrm{disc})$ as the standard. Suspension of each microorganism (100 $\mu \mathrm{l}$, containing approximately $100-150 \mathrm{CFU} / \mathrm{ml}$ ) was spread over nutrient agar medium and sterile filter paper discs ( $6 \mathrm{~mm}$ diameter) impregnated with different fractions were placed gently on those agar plates. The plates were then kept at $4^{\circ} \mathrm{C}$ for about $24 \mathrm{~h}$ to allow sufficient diffusion of the materials from the discs. The plates were then inverted and kept in an incubator at $37^{\circ} \mathrm{C}$ for $24 \mathrm{~h}$. After incubation, the diameter of the zones of inhibition was measured in millimeter.

Brine shrimp lethality bioassay. Brine shrimp lethality bioassay ${ }^{23}$ is a widely accepted technique for the initial toxicity screening of plant extract and others based on their ability to kill a laboratory cultured larvae .Artemia salina leach (brine shrimp eggs) were hatched for 48 hours in simulated sea water by maintaining $37^{\circ} \mathrm{C}$ and constant oxygen supply to get matured nauplii. A total of $4 \mathrm{mg}$ of each fraction sample was dissolved in $60 \mu \mathrm{DMSO}$ and solutions of 400, 200, 100, 50, 25, 12.5, 6.25, 3.125 and $1.562, \mu \mathrm{g} / \mathrm{ml}$ were obtained after serial dilution. 
In each experimental solution, $5 \mathrm{ml}$ seawater was added followed by 10 living nauplii. A negative control was prepared with $30 \mu \mathrm{l}$ of DMSO, $5 \mathrm{ml}$ of seawater and 10 living nauplii, while vincristine sulphate of different concentrations were used as positive control. After 24 hours, the number of survived nauplii was counted and the percentage of lethality of the brine shrimp nauplii was calculated for each concentration of the fractions.

Statistical analysis. Statistical analyses were performed using Microsoft Excel, 2010. All experiments were repeated three times and results were expressed as mean values \pm standard deviation (SD).

\section{RESULTS AND DISCUSSION}

Preliminary phytochemical screenings. Preliminary phytochemical screening of all fractions of $C$. aurantifolia peel revealed the presence of alkaloids, steroids, glycosides and saponins.

DPPH radical scavenging assay. The chloroform soluble fraction (CFCA) showed the highest free radical scavenging activity with $\mathrm{IC}_{50}$ value of $153.68 \pm 3.60 \mu \mathrm{g} / \mathrm{ml}$ and petroleum ether fraction (PECA) showed the lowest with $\mathrm{IC}_{50}$ value of $252.01 \pm 2.34 \mu \mathrm{g} / \mathrm{ml}$. The scavenging effect of all the fractions increased in a concentration dependent manner. The $\mathrm{IC}_{50}$ values of the three fractions and ascorbic acid are presented in the Table 1.

Total phenolic content. Total phenolic content of the test fractions were calculated using the standard curve of gallic acid ( $y=0.0053 x-0.1917$; $\mathrm{R}^{2}=0.814$ ). The chloroform (CFCA) fraction was found to contain the highest amount of phenols. Phenolic contents of the fractions were found to decrease in the following order: CFCA $(308 \pm 6.55$ $\mathrm{mg} / \mathrm{g}$ GAE $)>$ HMCA $(282 \pm 5.29 \mathrm{mg} / \mathrm{g}$ GAE $)>$ PECA (261.66 $\pm 1.52 \mathrm{mg} / \mathrm{g}$ GAE) (Table 1).

Total flavonoid content. The total flavonoid content was calculated using the standard curve of quercetin $\left(\mathrm{y}=0.003 \mathrm{x}-0.019 ; \mathrm{R}^{2}=0.955\right)$. HMCA was found to contain the highest flavonoid content $(132.66 \pm 2.36 \mathrm{mg} / \mathrm{g}$ QE) followed by CFCA (131.50 $\pm 4.44 \mathrm{mg} / \mathrm{g} \mathrm{QE})$ and PECA $(124.16 \pm 4.25 \mathrm{mg} / \mathrm{g} \mathrm{QE})$ (Table 1).

Antimicrobial activity. CFCA showed strong antimicrobial activity against all the tested bacteria (300 $\mu \mathrm{g} / \mathrm{disc})$ where the highest zone of inhibition $(19 \mathrm{~mm})$ was observed against Bacillus cereus and lowest $(13 \mathrm{~mm})$ against Salmonella typhi, Vibrio parahemolyticus, V. mimicus and Shigella boydii. Highest zone of inhibition was demonstrated by PECA $(11 \mathrm{~mm})$ against Pseudomonas aeruginosa and $S$. boydii. Mild antibacterial action was exerted by HMCA against some of the bacterial strains (Table 2).

Table 1. Antioxidant and cytotoxic activities of different fractions of $C$. aurantifolia peel.

\begin{tabular}{lcccc}
\hline Sample/ Standard & \multicolumn{3}{c}{ Antioxidant activity } & $\begin{array}{c}\text { Cytotoxicity } \\
\text { nyynn}\end{array}$ \\
\cline { 2 - 4 } & $\begin{array}{c}\mathrm{IC}_{50} \text { value } \\
(\mu \mathrm{g} / \mathrm{ml})\end{array}$ & $\begin{array}{c}\text { Total phenolic content } \\
(\text { in mg/g GAE) }\end{array}$ & $\begin{array}{c}\text { Total flavonoid } \\
\text { content (in mg/g QE) }\end{array}$ & $\begin{array}{c}\text { LC }_{50} \text { value } \\
(\mu \mathrm{g} / \mathrm{ml})\end{array}$ \\
\hline PECA & $252.01 \pm 2.34$ & $261.66 \pm 1.52$ & $124.16 \pm 4.25$ & 367.39 \\
CFCA & $153.68 \pm 3.60$ & $308.0 \pm 6.55$ & $131.50 \pm 4.44$ & 228.14 \\
HMCA & $214.07 \pm 0.89$ & $282.0 \pm 5.29$ & $132.66 \pm 2.36$ & 296.52 \\
AA & $18.16 \pm 1.79$ & - & - & - \\
VS & - & - & - & 1.81
\end{tabular}

Values are expressed as mean $\pm \mathrm{SD} ; \mathrm{n}=3$. PECA: Petroleum ether fraction; CFCA: Chloroform fraction; HMCA: Hydromethanol fraction; AA: Ascorbic acid; VS: Vincristine sulphate 
Table 2. Antibacterial activity of three fractions of $C$. aurantifolia peel.

\begin{tabular}{lcccc}
\hline \multirow{2}{*}{ Bacteria } & PECA & CFCA & HMCA & Kanamycin \\
\cline { 2 - 5 } & $300 \mu \mathrm{g} / \mathrm{disc}$ & $300 \mu \mathrm{g} / \mathrm{disc}$ & $300 \mu \mathrm{g} / \mathrm{disc}$ & $30 \mu \mathrm{g} / \mathrm{disc}$ \\
\hline Zone of inhibition $(\mathbf{m m})$ & & & & \\
\hline Gram positive bacteria & 10 & 19 & 8 & 30 \\
\hline Bacillus cereus & - & 14 & - & 30 \\
B. megaterium & 9 & 16 & - & 30 \\
B. subtilis & 7 & 17 & 6 & 30 \\
Sarcina lutea & - & 15 & - & 34 \\
Staphylococcus aureus & & & & 17 \\
\hline Gram negative bacteria & 9 & 15 & - & 35 \\
\hline Salmonella paratyphi & - & 13 & - & 13 \\
S. typhi & - & 13 & 6 & 30 \\
Vibrio parahemolyticus & 6 & 13 & 6 & 24 \\
V. mimicus & 9 & 16 & 8 & 28 \\
Escherichia coli & 10 & 15 & 8 & 23 \\
Shigella dysenteriae & 11 & 17 & - & \\
Pseudomonas aeruginosa & 11 & 13 & - & \\
S. boydii & & & & \\
\hline PEA: Petroum & & & & \\
\hline
\end{tabular}

PECA: Petroleum ether fraction; CFCA: Chloroform fraction; HMCA: Hydromethanol fraction; (-) means no zone of inhibition.

Brine shrimp lethality bioassay. All the fractions produced weak cytotoxicity against brine shrimp nauplii in concentration dependent manner. Among all the fractions, CFCA was found to show highest cytotoxicity $\left(\mathrm{LC}_{50}=228.14 \mu \mathrm{g} / \mathrm{ml}\right)$ followed by HMCA $\left(\mathrm{LC}_{50}=296.52 \mu \mathrm{g} / \mathrm{ml}\right)$ and PECA $\left(\mathrm{LC}_{50}=\right.$ $367.39 \mu \mathrm{g} / \mathrm{ml})$. The $\mathrm{LC}_{50}$ value for vincristine sulphate was $1.81 \mu \mathrm{g} / \mathrm{ml}$ (Table 1).

Secondary plant metabolites play important roles in the treatment of several diseases in traditional and modern medicine as well as provided lead compounds for new drug development. ${ }^{24}$ Preliminary phytochemical screenings of three fractions of methanol extract of $C$. aurantifolia peel revealed the presence of various secondary metabolites such as saponins, glycosides, flavonoids, alkaloids and steroids.

In DPPH radical scavenging assay, the violet color of DPPH was changed to a pale yellow color due to the abstraction of hydrogen atom from antioxidant compound and $\mathrm{IC}_{50}$ value was estimated as the quantity of antioxidant present in the sample that is required to decrease the initial DPPH concentration by one-half. Our present study showed moderate DPPH radical scavenging activity of all the fractions which is also consistent with the previous studies. ${ }^{25}$ Phenolic compounds and flavonoids have been described to be associated with antioxidative action in biological organisms, acting as scavengers of singlet oxygen and free radicals due to presence of multiple -OH group in their structures. ${ }^{26,27}$ Therefore, the interests on crude extracts of fruits, herbs, vegetables, cereals, nuts, and other plant materials rich in phenolics are gradually increasing. Diets rich in fruits and vegetables contain polyphenolic compounds and can potentially serve to inhibit mutagenesis and carcinogenesis in humans. ${ }^{28,29}$ In this study it has been found that, the fractions of $C$. aurantifolia peel are enriched in total phenolic and flavonoid content. The radical scavenging activity of these fractions can be attributed to its higher phenolic content.

In this study, the chloroform soluble fraction of C. aurantifolia peel exhibited significant antibacterial activity (300 $\mu \mathrm{g} / \mathrm{disc}$ ) compared to the standard kanamycin $(30 \mu \mathrm{g} / \mathrm{disc})$. This fraction exhibited potential antibacterial activity against $B$. cereus, $S$. lutea, B. subtilis, E. coli, and P. aeruginosa (16 - 19 
$\mathrm{mm}$ ). This potent antibacterial activity may be due to the presence of various chemical constituents like limonene, linalool, and citronellal in the essential oil from C. aurantifolia fruit peel. ${ }^{30}$ Essential oils are long known for their capability to bind with the cell membrane protein and increase membrane permeability. This results in leaking of cellular content and subsequent cell death. ${ }^{31}$

The degree of lethality shown by the extractives was found to be directly proportional to the concentration of the extractives ranging from the lowest to the highest concentration. The plant is reported here to contain several phytochemical constituents most notably alkaloids, flavonoids, glycosides and steroids. Again, reports exist on the role of alkaloids and steroids in cytotoxic activity of plant extracts. ${ }^{32-34}$ However, phenolic compounds used in clinical dentistry are also reported to show cytotoxicity by inhibiting cellular DNA in a concentration-dependent manner. ${ }^{35}$ So, the weak cytotoxicity of the fractions could be related to those phytochemicals present in the fractions though further studies are required before any conclusion is made.

\section{CONCLUSION}

Chloroform fraction of $C$. aurantifolia peel was found to be very active against all the bacterial strains. Our present study suggests that $C$. aurantifolia peel could be a potent source of wide variety of antimicrobial compounds which may act as lead molecules in drug discovery process. Studies are in progress in the laboratory to isolate the active components responsible for the bioactivities of the plant.

\section{ACKNOWLEDGEMENTS}

The authors are thankful to the authority of Department of Pharmacy, East West University, Dhaka, Bangladesh for providing proper facilities to conduct the research.

\section{REFERENCES}

1. Antolovich, M., Prenzler, P., Patsalides, E., McDonald, S. and Robards, K. 2001. Methods for testing antioxidant activity. Analyst. 127, 183-198.

2. Patel, R., Rinker, L., Peng, J. and Chilian, W.M., 2018. Reactive Oxygen Species (ROS) in Living Cells, IntechOpen, Chapter 2, p. 7.

3. Pizzino, G., Irrera, N., Cucinotta, M., Pallio, G., Mannino, F., Arcoraci, V., Squadrito, F., Altavilla, D. and Bitto, A. 2017. Oxidative stress: harms and benefits for human health. Oxid. Med. Cell. Longev. 2017, 1-13.

4. Shanta, M. A., Mondal, M., Majumder, S., Islam, I., Hoque, N., Tithi, N. S., and Rana, S. 2018. Pharmacological investigations of chloroform extract of Stereospermum chelonoides leaves. Int. J. Pharm. Sci. 9, 4256-4266.

5. Yuan, L., Mishra, R., Patel, H., Abdulsalam, S., Greis, K. D., Kadekaro, A. L., Merino, E.J., and Garrett, J. T. 2018. Utilization of reactive oxygen species targeted therapy to prolong the efficacy of BRAF inhibitors in melanoma. $J$. Cancer. 9, 4665-4676.

6. Sidana, J., Saini, V., Dahiya, S., Nain, P. and Bala, S. 2013. A review on Citrus-the boon of nature. Int. J. Pharm. Sci. Rev. Res. 18, 20-27.

7. Hughes, D. and Karlén, A. 2014. Discovery and preclinical development of new antibiotics. Ups. J. Med. Sci. 119, 162169.

8. Enejoh, O., Ogunyemi, I., Bala, M., Oruene, I., Suleiman, M. and Folorunsho. A. S. 2015. Ethnomedical importance of Citrus aurantifolia (Christm) swingle. Pharma Innovation. 4, 1-6.

9. Roy, D. and Rahman, A.H.M.M. 2016. Systematic study and medicinal uses of Rutaceae family of Rajshahi district, Bangladesh. Plant Env. Dev. 5, 26-32.

10. Pathan, R., Gali, P., Pathan, P., Gowtham, T. and Pasupuleti, S. 2012. In vitro antimicrobial activity of Citrus aurantifolia and its phytochemical screening. Asian Pac. J. Trop. Dis. 2, 328-331.

11. Ibrahim, F., Usman, L., Akolade, J., Idowu, O., Abdulazeez, A. and Amuzat, A. 2018. Antidiabetic potentials of Citrus aurantifolia leaf essential oil. Drug Res. (Stuttg).69, 201-206.

12. Yaghmaie, P., Parivar, K. and Haftsavar, M. 2011. Effects of Citrus aurantifolia peel essential oil on serum cholesterol levels in Wistar rats. J. Paramed. Sci. 2, 29-32.

13. Kabbashi, E., Ali, S. and Abdelrahman, N. 2016. Lime (Citrus aurantifolia L.) juice a potent treatment for the virulent hepatocarcinogen aflatoxin B1 in peanut paste. $J$. Mol. Pathophysiol. 5,18-22.

14. Hoque, N., Sohrab, M. H., Debnath, T. and Rana, M.S. 2016. Antioxidant, antibacterial and cytotoxic activities of various extracts of Thysanolaena maxima (Roxb.) Kuntze available in Chittagong hill tracts of Bangladesh. Int. J. Pharm. Pharm. Sci. 8, 168-172. 
15. Hoque, N., Rahman, S., Jahan, I., Shanta, M.A., Tithi, N.S. and Nasrin, N. 2018. A comparative phytochemical and biological study between different solvent extracts of Bombaxceiba roots available in Bangladesh. Pharmacol. Pharm. 9, 53-66.

16. Islam, M. I., Shanta, M. A., Mondal, M., Hoque, N., Majumder, S., Ahmed, T. andRana, M. S. 2018. Protective effect of chloroform extract of Stereospermumchelonoides bark against amyloid beta42 induced cell death in SH-SY5Y cells and against inflammation in Swiss albino mice. J. Basic Clin. Physiol.Pharmacol. 29, 621-630.

17. Rahman, G.M.S, Haque, N and Rashid, A. 1999. Cytotoxic activity of Commelinabenghalensis Linn. Usingbrine shrimp lethality bioassay. Bangladesh J. Pharmacol. 15, 62-65.

18. Ghani, A. 2003. Medicinal Plants of Bangladesh with Chemical Constituents and Uses. Asiatic Society of Bangladesh, pp. 45-48.

19. Braca, A., De Tommasi, N., Di Bari, L., Pizza, C., Politi, M. and Morelli, I. 2001. Antioxidant principles from Bauhinia terapotensis. J. Nat. Prod. 64, 892-895.

20. Irkin, R., Dogan, S., Degirmencioglu, N., Diken, M. and Guldas, M. 2015. Phenolic content, antioxidant activities and stimulatory roles of Citrus fruits on some lactic acid bacteria. Arch. Biol. Sci. 67, 1313-1321.

21. Kumaran, A. and Karunakaran, A.J. 2007. In vitro antioxidant activities of methanol extracts of five Phyllanthus species from India. LWT - Food Sci. Technol. 40, 344-352.

22. Bauer, A.W., Kirby, W.M.M., Sherris, J.C. and Turck, M. 1966. Antibiotic susceptibility testing by a standardized single disc method. Am.J.Clin. Pathol. 45, 493-496.

23. Meyer, B.N., Ferrigni, N.R., Putnam, J.E., Jacobsen, L.B., Nichols, D.E. and McLaughlin, J.L. 1982. Brine shrimp: a convenient general bioassay for active plant constituents. Planta Med. 45, 31-34.

24. Hussein, R. A. and El-Anssary, A. A., 2019. Plants secondary metabolites: the key drivers of the pharmacological actions of medicinal plants. Herb. Medic.13-16.

25. Loizzo, M. R., Tundis, R., Bonesi, M., Menichini, F., De Luca, D., Colica, C., and Menichini, F. 2012. Evaluation of Citrus aurantifolia peel and leaves extracts for their chemical composition, antioxidant and anti-cholinesterase activities. $J$. Sci. Food Agric. 92, 2960-2967.
26. Rice-Evans, C., Miller, N., and Paganga, G. 1997. Antioxidant properties of phenolic compounds. Trends Plant Sci. 2, 152-159.

27. Jørgensen, L. V., Madsen, H. L., Thomsen, M. K., Dragsted, L. O., and Skibsted, L. H. 1999. Regeneration of phenolic antioxidants from phenoxyl radicals: an ESR and electrochemical study of antioxidant hierarchy. Free Radic. Res.30, 207-220.

28. Tanaka, M, Kuie, C.W, Nagashima, Y and Taguchi, T. 1988. Applications of antioxidative maillard reaction products from histidine and glucose to sardine products. Nippon Suisan Gakkaishi. 54. 1409-1414.

29. Mazumder, M.E.H, Alam, B, Alam, M.A, Jamila, M and Muhsin, M.D.A. 2009. Investigations of secondary metabolites, antioxidant and cytotoxic activities of the leaf extract of Portulaca oleracea L. Bangladesh J. Life Sci. 21, $17-22$.

30. Lemes, R. S., Alves, C. C., Estevam, E. B., Santiago, M. B., Martins, C. H., Santos, T. C. D., Crotti, A.E.M. and Miranda, M. L. 2018. Chemical composition and antibacterial activity of essential oils from Citrus aurantifolia leaves and fruit peel against oral pathogenic bacteria. An. Acad. Bras. Cienc. 90, 12851292 .

31. Vieira, T. M., Dias, H. J., Medeiros, T. C., Grundmann, C. O., Groppo, M., Heleno, V. C. and Silva, E. O. 2017. Chemical composition and antimicrobial activity of the essential oil of Artemisia absinthium asteraceae leaves. $J$. Essent. Oil-Bear. Plants. 20,123-131.

32. Dhar, M.L, Dhar, M.N, Dhawan, B.N, Mehrotra B.N, Srimat, R.C and Tandon, J.S. 1973. Screening of Indian medicinal plants for biological activity. Indian J. Exp. Biol. 11, 43-45.

33. Vijayan, P, Rreethi, V., Prashanth, S.H., Raghu, C. H., Ashok, G., Shrishailappa, B., Arumugum, D.S. and Bhojraj, S. 2004. Cytotoxicity activity of the total alkaloids isolated from different parts of Solanum pseudocapsicum. Biol. Pharm. Bull. 27, 528-530.

34. Badami, S., Manohara, R. S.A., Kumar, E.P., Vijayan, P. and Suresh, B. 2003. Antitumor activity of total alkaloid fraction of Solanum pseudocapsicum leaves. Phytother. Res. 17, 1001-1004.

35. Chang, Y.C., Tai, K.W., Huang, F.M., and Huang, M.F., 2000. Cytotoxic and nongenotoxic effects of phenolic compounds in human pulp cell cultures. J. Endod. 26, 440443. 